\title{
Nautanki in the time of Independence Struggle: the Tangled History of Sāngīts and Akhäräs
}

\author{
Rittvika Singh \\ Delhi College of Arts \& Commerce, University of Delhi, India. Orcid Id: orcid.org/oooo- \\ ooo2-1725-0634. Email: rittvika.singh@gmail.com \\ Received May 30, 2017; Revised July14, 2017; Accepted July 20, 2017; Published August 16, 2017.
}

\begin{abstract}
Nauțanki theatre of North India is a popular cultural institution that offers an opportunity to document the history of the un-imagined community. However, the historical accounts of this theatre are either obscure or they present a very limited view of Nautanki. During the decades of India's struggle for independence, Nautankī became a platform for registering protest. While there are well corroborated accounts of the progressive Indian People's Theatre Association involvement in mobilizing the masses for struggle, there appears a regrettable gap that withholds the process of making informed assumptions while studying Nautanki's participation. Through the examples drawn from the two different akaharas (schools) of Nauțanki- Hathras and Kanpur, this paper attempts to highlight the existence of lacunas that mar the historiography of the lesser known, hence exposing the loopholes in the purported idea of writing history from the margins. In the process it also describes the ways in which Nautanki has exhibited the potential of being a vital forum for protest, though its image in the general perception is merely of an obscene medium of entertainment. Apart from discussing the few available records that document Nautanki's participation, the paper constructs its premise on the interviews and material collected during the field visits in Allahabad and adjoining areas which have supplemented the inferences and observations drawn.
\end{abstract}

Key words: Nautanki, Alternate Historiography, Popular culture, Independence struggle, Masses.

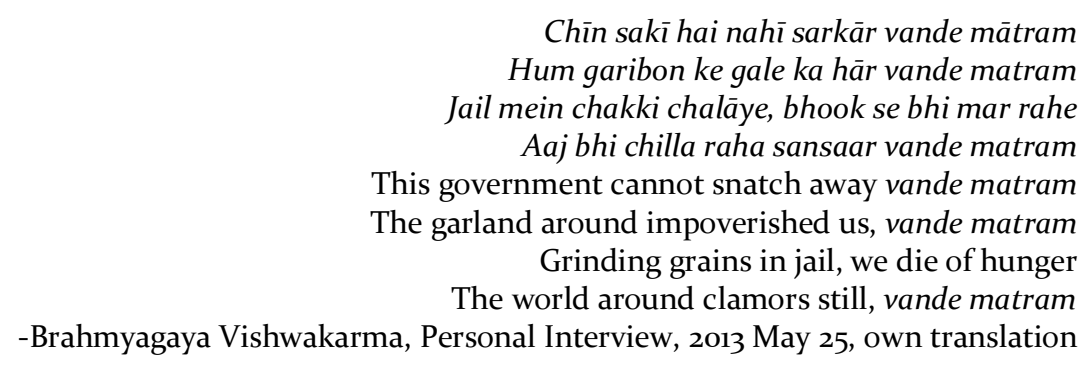

An octogenarian Nautankī actor from the days of India's struggle for independence spurts out these lines when I ask him about Nautankì of his times. Brahmyagya Vishwakarma has seen generations of Nautanki since India woke up at the midnight and he still fondly remembers the days when Nautankī in Allahabad was rubbing shoulders with Lal Bahadur Shastri and Jawaharlal Nehru. Vishwakarma is no more now and the information (though unverifiable) that was mnemonically registered will soon become the part of hearsays. Subaltern studies have perennially laid emphasis on an alternate historiography that would deconstruct the dominant

(C) AesthetixMS 2016. This Open Access article is published under a Creative Commons Attribution Non-Commercial 4.0 International License (http://creativecommons.org/licenses/by-nc/4.0/), which permits non-commercial re-use, distribution, and reproduction in any medium, provided the original work is properly cited. For citation use the DOI. For commercial re-use, please contact editor@rupkatha.com. 
narratives and unearth the hitherto marginalized accounts. In the conception of the idea that envisages a nation as a whole, the exclusive structures built by the privileged conveniently fragment and erase the narratives of masses that appear to them as an interruptive noise. A historiography that accounts for the discarded noises not only aids in providing a better hermeneutic framework but also suggests novel paradigms of interrogation. Nautanki theatre of North India is one such 'noise' that has been conveniently and ignorantly relegated to a crass and low brow medium of entertainment that in general perception supposed to be of no significance whatsoever at least in the political imagination of the nation, if not a cultural one. On the cultural front it still does have some stake no matter how generalized and nominal, courtesy Suresh Awasthi's "theatre of roots" and the historical accounts listing the Sanskrit and popular theatres of India. In the era of post-independence existential crises, modern Indian theatre in its desperate attempt to find an "indigenous idiom" (Dalmia 2006, p. 153) attempted to exhume and resuscitate the traditional forms of theatre to ascribe a certain sense of peculiar Indianness to the theatre of India. Through the initiatives of government sponsored institutions and the renowned theatre practitioners, the urban theatre of India turned towards its villages and forms like Nautankī, Tamāshā, Bhavai, Jātrā, Burrākathā, Yakshagāna became the natural adoptions. The urban theatre, thus in the fit of its own kind of swadeshi movement, transformed itself to what Aparna Dharwadker calls "urban folk" (p. 320). This approach, however, patronized folk and often sought to ameliorate it, brought the folk theatres like Nautanki in the purview of cultural image of the nation. Even in the discussions of some of the most cited and celebrated works that chart the history of Indian theatre, folk forms are given merely honorary mentions sometimes circumscribed within a paragraph each. Many of the works that mention or refer to Nautanki are of the nature of compendiums or encyclopedias that enlist many other traditional or folk theatres of India, thus trivializing each one of them by giving nominal attention. This kind of documentation has resulted in obscurities and archival irregularities that have happened because of the limited scholarly attention and also the sparsely available performative texts. In this scenario, to study Nautanki's involvement in the national life of India is indeed a daunting task as it throws the challenge of placing the texts within a chronology and sequence of contexts at the time they occurred in the performances.

\section{Nauțankī: A Brief History}

Before venturing into further discussion, it would be pertinent here to give a brief introduction and outline of Nautankī theatre. Nautankī is a musical theatre of Uttar Pradesh which shares its contours with similar forms like that of Khyāl, Bhagat, Rahas, and Swāngii. Nautankī's performance includes singing and dancing with the accompaniment of musical instruments such as nakkārā (kettledrums) and harmonium. Dialogues are in the form of verse like doha (couplets), chaubolä (four lines that begin with the last phrase of the preceding couplet and also rhyme with each other) and beher-e-tavil (a long metrical verse) which are sung throughout the performance. It has been a huge medium of entertainment during the late nineteenth and early twentieth century in north India. The Nautanki theatre has a huge body of performative texts called Sangit and even today one can find copies of the popular Sāngìts (of Natharam Sharma Gaur of Hathras and Srikrishna Pehelwan of Kanpur) with local chapbook vendors in small towns of Uttar Pradesh and even Bihar. However, this poses a problem for a researcher as it becomes difficult to ascertain the original date of any of these texts owing to the multiple reprints and authors who adapted texts from each other. The narratives of Nautanki that were performed on stage have a wide canvas as they swing from mythological stories to romances and even drama of human relationships. It stretches its contour by incorporating various stories from Persian legends and 
life stories of local heroes. Raja Harischandra, Amar Singh Rāthore, Roop Basant, Bhakt Puranmal, Shehzādi Nauțankī, Syāh-Posh, Lailā-Majnū, Shīrīn-Farhād, Dākū Sultānā, Moradhwaj, Gopichand, Indal Haran, are some of the narratives that have stood the test of time and have become synonymous with Nautankī. Amongst many schools/troupes of Nautankī that performed in the time, Hathras and Kanpur schools have been the most popular for their distinct style of performance. Nautankī, among the various debatable etymologies, derives its name from an eponymous female character of a popular Sāngìt Rānī Nauțankī kā (1882) [Agrawal, p. 136 and Hansen, p. 56]). Written by an author named Khushi Ram, this story is a romance of a beautiful princess of Multan and a commoner Phool Singh and how they unite at the end after the princess saves him from the wrath of her father. Down the years Nautanki as a theatre degenerated into song and dance sequences that were very often risqué, and earned a bad name. Owing to the presence of cinema and other mediums of entertainment, Nautankì today is present either in the deformed condition with local orchestra troupes or in the multiple attempts that have genuinely tried to keep it alive.

\section{The Obscurity of Undocumented}

The central idea of the paper engages itself with the time period when Nautanki became an instrument of mobilization and protest in colonial India. For the purpose of the research, several interviews were taken during the field visit in Allahabad. Some of the people who were interviewed are Atul Yaduvanshi, an exponent of Nautankī and director of Swarg repertory in Allahabad, Late Brahmyagya Vishwakarma and his son Ram Lochan Vishwakarma who have been performing Nautankī from four generations in Allahabad and Raj Kumar Srivastav, who has been associated with Nautankī through his journalistic and creative writings. Srivastav has been adapting Premchand's stories and Kalidasa's plays to Sāngìt for performances at various cultural platforms since the 1980 s. The interviews have unearthed a vital school of Nautanki that proves to have participated actively in the freedom struggle. Pt. Ramraj Tripathi based in Phaphamau, Allahabad formed his Sri Ram Sangit Mandali in 1913 and had performed Nautankīs in and around the region to mobilize people for the struggle. The troupe was so popular that even Nehrus had close affiliation with it. His sons Pt. Satti Ram Sharan and Pt. Jai Jairam Tripathi remember the first song that their father's troupe sang "Azaadi ka nishaan mor tiranga jhanda na /lehere sara Hindustan mor tiranga jhanda na (The symbol of freedom is my tricolor flag/unfurling all over the Hindustan is my tricolor flag.") [Srivastav, p. 35, own translation] ${ }^{\mathrm{iii}}$. Atul Yaduvanshi, Ram Lochan Vishwakarma, Late Brahmyagya Vishwakarma and Raj Kumar Srivastav recall of hearsay when Kamala Nehru while speaking from the stage of a Nautanki performance was hair-dragged by a British policeman. They talk vividly of an incident when Lal Bahadur Shastri disguised as Nautanki actor to hide from the British police force. They also remember the time when the usual plays of Nautanki were transformed into vehement protest against the foreign rule, through some tweaking of the characters and plot line. Late Brahmyagaya Vishwakarma, an octogenarian actor who had the zest to sing lines from Sāngit Moradhwaj for the interview, adds "aur jaise hi Angrezo ke sipahi aate thein hum fir se wahi purana gana shuru kar dete thein" (The moment British police men used to come we went back to performing our old songs. Lest they charge us with sedition). An article "Nautanki Again" that appeared in Frontline (2012, August 11-24) talks about the history and continuity of Nautankī theatre in Allahabad. It also recounts (though misspelling Pt. Ramraj Tripathi's name):

In pre-Independence India, Nautankī was used to spread messages of patriotism. Between 1924 and 1936, it was banned in Allahabad. Jawaharlal Nehru was deeply interested in the 
theatre form. During one of his stints in jail, he met Ramdas Tripathi, a well-known Nautankī director from Allahabad. They became friends, and Nehru started calling upon folk theatre directors/artistes to spread the message of nationalism. Nautanki groups would help to collect audiences when nationalist leaders delivered speeches at public meetings. (Zaman, para. v)

Nandini Gooptu in her book The Politics of Urban Poor in Early Twentieth-Century India (2001) gives a detailed description of Ramlila processions in Allahabad around the same period and infers that these processions marked an "intermeshing of nationalist images with Hindu symbolism"(p. 232). Citing a government document, she reports:

The figure of Bharat Mata or the Mother India, Mahatma Gandhi, Shivaji and Rani of Jhansi graced the processions, alongside images of charkha spinning and British police atrocities such as at Jallianwala Bagh. The revered figure of Ram, Lakshman and Sita were dressed in khadi clothes with their denigrated adversary Ravana in foreign outfit. (p. 232)

Ramlila and Nauțankī both belong to the carnivelseque (Bhaktin 1984, p. 5) life of the common people. They also hold a potential to mould and change the course of public imagination and spirit. While Ramlila was doing so, as mentioned by Gooptu, Nautankī could not be far behind especially when the distancing of the decent audience from Nautanki had not started by then. While laying the emphasis on the documentation of the 'politics of people' and the inadequacy of the elitist historiography, Ranajit Guha, in his Introduction to Subaltern Studies I (1982) discusses that the exclusive history documented by the elites is very telling of their affiliations and internal contestations. He writes:

Elitist historiography is of course not without its use. It helps us to know more about the aspects of ideology of the elite . . . as the dominant ideology of the period; about the contradictions between the two (the colonial and their Indian counterpart) elites and the complexities of their mutual oppositions and coalitions.... (p. 2-3)

Such an observation, when extended to the historiographies attempted in the wake of writing a counter narrative from the margins, does not reveal any such understanding. These historiographies work under the assumption of the margins as the uni-layered, homogenous and sanctified whole hence falling in the same trap of elitist one. The study of the tradition/performative texts of Nautanki attempted here forth will not only reveal these contradictions but also try to lay out the problems of documentation that precedes any kind of historiography.

\section{The Problems of Documented}

Kanpur akhara's contribution has been relatively more frequently documented. Kathryn Hansen in her ground breaking work Grounds for Play: Nautankī Theatre of North India (1992, reprint 1993) talks about an important performative texts titled Zulmi Dyer (1922) of Kanpur school. It is an oft mentioned text as it openly criticized the Jallianwala Bagh massacre and General Dyer (p. 110). Ram Naryan Agrawal too in his book Sāngìt: Ek Lok Nātya Paramaparā (1976) mentions of the time when actors Moti and Buddhi Master of Srikrishna Pehelwan's school used to roam around and mobilize people singing "Rang laegi hina pattthar pe pis jane ke baad (The henna will exhibit color only after being grinded on stone" [p. 131 own translation]). It was around the same time that Tripathi's troupe had performed Nautankīs in and around Allahabad to mobilize people for the struggle. During the course of research in this region, an article written by Raj Kumar 
Srivastav that appeared in a magazine Hindi Digest Navneet (1988) was generously shared with me. The article informs of Nautankìs involvement in the freedom struggle though without mentioning dates of almost all of such productions. The article mentions of a Sāngit titled Gandhi Haran urf Sapne ka Kamaal by one Lala Babu Lal of Mursaan, Aligarh. It is an undated account of a fictional event where Mahatma Gandhi is kidnapped and taken away to London. The Commissioner of Police is compelled to set Gandhi free when his son makes him realize that Gandhi is a god-like figure and imprisoning him would be a sin. This Sāngit takes its title after the famed Indal-Haran (where a fairy falls in love with a commoner and kidnaps him) and makes Gandhi a very important figure for the audiences. The Commissioner in the Sängìt says:

Chhoru main Gandhi veer ko dhar dhir dil lakht-e-jigar

Kehna tera beta karu, tu chhor de ranjo fikar

Aaya main central jail se, khola kulafjis dum maine

Hai satyadhari veer ko,bahar kiya ekdum maine. (p. 53)

I will set the brave Gandhi free, be patient my dear son

I will do as you say, do not worry and be sad

I will go to central jail now and release him right away

I will set that truthful brave man free. (p. 53, own translation)

The same article also mentions of a Nautankī supposedly published in 1924 Pita-putra arthat Prahlad ka Satyavrat by Pt. Kanhaiya Lal Chaturvedi of Haldwani which makes the character of a Prahlad a staunch satyagrahi who instigates his friends against the British rule as he says:

Is Adharam ke shok me Bharat hai bharpur

Lekin dahshat ke sabab hain sab hi majboor

Dahshat se sab majboor hain, lagta na ye kisko bura

Satdharm par jo chal raha, annyaya paapi ka chhura

Aisa banaya act jo biran saha jata nahin...

Kis tarah pao fatah tum shanti ke hathiyar se

Bhagwan hi raksha karein, annyayiyon ke var se. (p. 53)

Bharat, India is in the gloom of unrighteous

But for the fear of atrocities, all are victims

All are victims for fear, none feels bad about it

The knife of sinful injustice slays the righteousness

Such act has been passed that has become unbearable, brothers. .

How would you win it with the weapon of peace

Only God can save from the attack of these purveyors of injustice. (p. 53, own translation mine)

It also refers to another Sāngìt Veer Baalak (1931) by Sri Krishna Pehelwan which is "actually different from what it appears" (54) and has songs like:

Hum desh pe kurbaan hai hum desh ke shaidai

Azad ho rahenge azadi pasand aayi

Hum desh ki sewa se muh ko na kabhi morey

Hinsatmak na honge, hinsa hai dukhdayi

Partantrata mitey tab hilmil ke jab rahe sab

Sar sabz dega us din hinde chaman dikhayi (p. 54)

We sacrifice our lives for the country, we are madly in love with our country

We will be free we love freedom

We will never turn away from the service of our country 
We will never be violent, violence is painful

The shackles of foreign rule can be broken if we are united

On that day Hind, India will look happy and prosperous. (p. 54, own translation)

It also goes on mentioning several other Sāngìts like Subhash Chandra Bose, Kaumi Diler urf Bharat Saput, Baliya ke Sher (based on the life of the revolutionary Chittu Pande of Balia, Uttar Pradesh), Rani Laxmibai etc. without any date of their performance or publication. Unavailability of the dates makes these texts free to be easily appropriated and credits Nautanki of deeds that might have been committed sporadically and not even before 1947. Contrary to the examples cited, Sāngìt Amar Singh Rathore (first published in 1912 as cited by Hansen, p. 97) gives a very different perspective as it begins with 'Maharani Elizabeth ko ashirwad' (Blessings to the Queen Elizabeth II) written in Devnagri:
Elizabeth dwitiya (second) empress, good gracious strong
Prayer this ours is, may you live long long
May you live long long rule beneficent continue
Fortunate we are all having queen good like you
Under English sovereigns we received blessings new new
All of them had to do good to us in their view
Your gracious majesty. Of the same dynasty.
Your nature too kind
Long rule be your sincerely we pray combined" (Gaur, p. 1-2)

However, such eulogy of the Queen or the British rule is an exception and not found in other texts. If Nautanki became a platform to mobilize masses for the struggle for independence as evident through the interviews and the above mentioned document, then there is a fair chance of it swaying to the other side as well owing to the commercial interest of the Nautanki companies. Was it the coercive Dramatic Performance Censorship Act of $1876^{\text {iv }}$ that necessitated the submission of a "copy of the piece, if and so far as it is written, or some sufficient account of its purport, if and so far as it is, in pantomime, has been furnished, not less than three days before the performance, to the Local Government, or to such officer as it may appoint in this behalf" (Bhatia, 2009, p. 429) that (might have) compelled the writers to include such an 'ashirwad'? Was it merely a strategy to sell the performance by incorporating the fashionable though incomprehensible foreign language for audience? All the people interviewed here have registered their doubts for the number of medals Natharam Sharma Gaur flaunted in the picture on the cover of his Sāngits.

According to them, these were the medals bestowed upon him

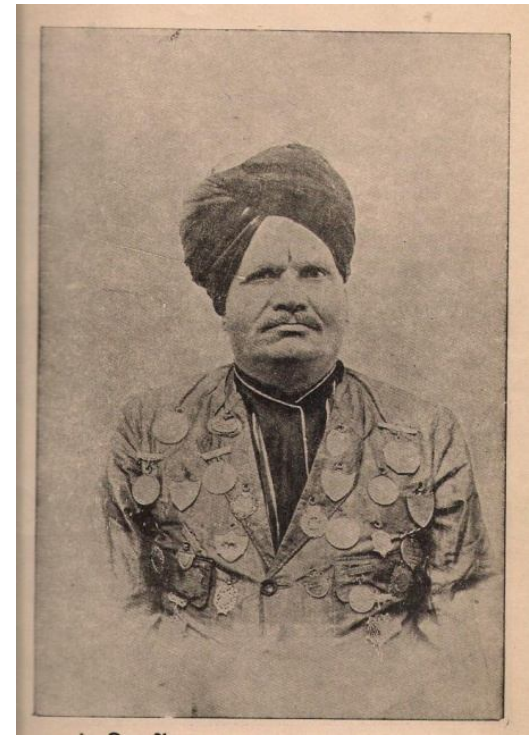

Figure 1: Natharam Sharma Gaur of Hathras with all his medals by the British government. This leads to further questions and makes one wonder about the possibility of these akhārās being ideologically different.A lack of similar and more prudent information in other sources, however limits the veracity of such an interpretation. It is a possibility that the character of protest in the Sangits as cited in the article above would have been primarily present in the performance only and the article is possibly referring to them alone and not the written word. Rakesh H. Solomon in his insightful article "Culture, Imperialism and 
Nationalist Resistance: Performance in Colonial India” (1994, Oct.) pertinently discusses the strategies that dramatist employed to stage the performances of protest and resistance. He says:

The dramatists also utilized such subjects because the audience was intimately familiar with these historical and mythic plots and personalities and was thus alert to their accumulated meanings, associations, and resonances. Such coded sources facilitated subtle, indirect, and surreptitious communication. Just as importantly, the audience loved and revered the heroic characters, whether from history, legend, myth, or religious epic. Given such an attitude, the playwrights of the Indian resistance could count on their heroic characters' veiled political exhortations to carry nearly religious sanction and urgency. Not accidentally, these stories, then as now, also guaranteed crowded theatres. Finally, in the context of the Independence movement, simply by depicting India's heroic past, the dramatists inspired patriotism, encouraged participation in the freedom struggle, and offered an antidote to spreading cultural colonization. (p. 327)

Darius L. Swann in his informative essay "Nautanki and the Struggle for Independence, National Integration, and Social Change: A Brechtian Analysis" cites examples from the texts of Kanpur school and shows how they became a significant way of protesting against the British rule. The fact that none of the texts (except Baliyā ke Sher) and excerpts cited above, figure in his article shows not only a lacuna in the documentation but also the written history of Nautanki. Nandi Bhatia in her seminal work Acts of Authority/Acts of Resistance: Theatre and Politics in Colonial and Postcolonial India (2004) discusses Dinbandhu Mitra's Nil Darpan (translated, published and circulated by James Long of Church Missionary Society in 1860) as the first nationalist drama from Bengal that became turning point in the history of anti colonial protest while simultaneously establishing "theatre as a powerful weapon of resistance in the struggle for independence from the colonial rule" (p. 22). This kind of historiography depends heavily on documentation of the performances and also of the reaction it must have generated then. The intelligentsia of Bengal and their English counterparts had played a key role in forming a powerful archival base that records such information, whereas a parallel process that could have aided the study of indigenous theatre like Nautankī is either absent or lacking. Additionally, Bhatia also notes the obstructions in reading the institution of theatre from a historical perspective. She writes:

Unlike literature that finds its ultimate expression in print, theatre's incompatibility with infinite mechanical reproducibility, its ephemeral and live aspects, cultural and theatrical conventions - such as the folk performances of the jatras, which could last from several hours to several days- pose the problem of documentation and recovery. (p. 3)

As indicated earlier as well, it is only because of these frequent gaps in the ontology and imprecise chronological constructions that a study which would have revealed a wide discourse of nationalism through a hermeneutic understanding of these performative texts remains blurred. Apart from this, while there is an immense availability of reprints and versions of many other narratives (Rājā Harischandra, Amar Singh Rāthore, Roop Basant, Bhakt Pūranmal, Shehzādi Nauțankī, Syāh-Posh, Lailā-Majnū, Shīrīn-Farhād, Dākū Sultānā, Moradhwaj, Gopichand, Indal Haran etc.), the absence of the above mentioned texts in reprints and their exclusive location in the British Library highlights the degree of censorship that was practiced by the British authorities. All of the information gathered during the field trip and the interviews become 
extremely precarious in the absence of any alternate narrative At best, it sounds like a very intriguing tale or a folk lore that has been passed onto generations. The claims made by the informants and the few accounts thus pose a challenge to the historiography that seeks to deconstruct the dominant narratives and unearth the hitherto marginalized accounts. Moreover, the presence of such an important school in a region is symptomatic of the existence of similar ones in other areas as well and any comprehensive history of Nautankī should account for that.

There have been many attempts to study Indian traditional theatres like Nautankī by scholars and theatre practitioners. These studies mainly focus on the theatricality and performance of these forms and vaguely discuss their role in the crucial historical moments in both the colonial and post-colonial times. Such a study, however, depends entirely on archival research and presence of lacunas obstructs and many times leads to fallacious interpretations. However, a scholarship that can engage with these aspects in detail will not only expose new ways of historiography but also level the chasm that appears as an impediment in claiming the spaces in the larger narrative.

\footnotetext{
Notes:

i The recommendations of the 1971 'National Roundtable on Contemporary Relevance of Traditional Theatre' organized by Sangeet Natak Akademi laid the official foundation of what was to be named as 'Theatre of Roots' later. Suresh Awasthi, the then General Secretary of Sangeet Natak Akademi along with Nemichandra Jain, a theatre scholar, was pushing for the adaptation of folk forms for the urban stage . He visualized a theatre that would be different from the western realistic theatre which was being practiced in the post-independence India. However, even before this coinage Habib Tanvir, Dina Gandhi, Ratan Thiyam and others were experimenting with the folk forms.

ii Bhagat and Swang are predecessors of Nautanki. Bhagat, was performed in mainly Braj region and was more on the religious themes (much like miracle plays) but had performance much similar to Nautanki. Swang which is primarily popular in Haryana was the non-religious performance. After the publication and popularity of the Sangit Nauțanki Shehzadi, the entire tradition assumed its name. (For a detailed history of this tradition see Ram Narayan Agrawal's Sangit : Ek Loknatya Parampara pg 40-137, Kathryn Hansen's Grounds for Play : Nauțankī Theatre of North India pg 56-116)

iii The interview appeared in the journal Nauțankī Kala (July, 1983) started by Nauțankī Kala Kendra in 1980s. The Kendra and its effort died with the patron head Munindra Nath Goswami 'Kakkuji'.

iv The Act was enforced by the British to curb the performances of the seditious nature. For the same purpose the theatre troupes performative text and performance were subjected to strict scrutiny. Any play defying the act was punished with heavy fine, punishment and even legal action.
}

\section{References:}

Agrawal, Ram Narayan. (1976). Sāngīt: Ek Loknātya Paramparā. Delhi: Rajpāl \& Sons.

Bakhtin, Mikhail M. (1984). Rabelais and His World. Trans. Helene Iswolsky. Bloomington: Indiana University Press.

Bhatia, Nandi (2009) ed. Modern Indian Theatre. New Delhi: Oxford University Press. 
---. (2004)Acts of Authority/Acts of Resistance: Theatre and Politics in Colonial and Postcolonial India. New Delhi: Oxford University Press.

Dalmia, Vasudha. (2006). Poetics, Plays and Performances: The Politics of Modern Indian Drama. New Delhi: OUP.

Dharwadker, Aparna Bhargava. (2005). Theatres of Independence: Drama, Theory and Urban Performance in India since 1947. Iowa City: University of Iowa Press,

Gaur, Natharam Sharma. (1987) Sāngīt Nauțankī Shehzādi Urf Ayyāra Aurat. Hathras: N.S. Sharma Gaur Book Depot.

---. (1994) Sāngìt Amar Singh Rathor urf Agare ki Larai. Hathras: N.S. Sharma Gaur Book Depot.

Gooptu, Nandini. (2003). The Politics of Urban Poor in Early Twentieth-Century India. Cambridge University Press (Virtual Publishing). Retrieved from http://assets.cambridge.org/97805214/43661/sample/9780521443661ws.pdf.

Guha, Ranajit. (1982). Some Aspects of the Historiography in Colonial India. In Ranajit Guha (Ed.) Subaltern Studies I: Writings on South Asian History and Society (pp. 1-9). New Delhi: Oxford University Press.

Hansen, Kathryn. (1993) Grounds for Play: Nautanki Theatre of North India. New Delhi: Manohar Publishers.

Solomon, Rakesh H. (1994), Oct.). Culture, Imperialism, and Nationalist Resistance: Performance in Colonial India. Theatre Journal, 46(3), 323-347. doi 10.2307/3208610.

Srivastav, Sanjay 'Pankaj'. (1983, July). Illahabad Nautanki ke avshesh [The Remnants of Allahabad's Nautanki." Natanki Kalā, 34-37.

Srivastav, Raj Kumar. (1988 August). swatantra sangram me Nautanki ka yogdan [Nautanki's Contribution in the Struggle for Independence]. Hindi Digest Navneet, 52-57.

Swann, Darius L. (1995). Nautanki and the Struggle for Independence, National Integration, and Social Change: A Brechtian Analysis. In Patrick Colm Hogan and Lalita Pandit (Ed.) Literary India: Comparative Studies in Aesthetics, Colonialism, and Culture. (pp. 189-205) Albany: State University of New York Press.

Vishwakarma, Brahmyagaya. (2013, May 25) Personal Interview.

Zaman, Rana Siddiqui. (2012, August 11 24). "Nautanki Again.” Frontline. Retrieved from http://www.frontline.in/static/html/fl2916/stories/2012082429161070o.html.

Rittvika Singh is a Ph.D. scholar in the Department of English, Banaras Hindu University, working on Nautanki theatre of North India. She is currently working as Assistant Professor (English) at Delhi College of Arts \& Commerce, University of Delhi. Orcid Id: orcid.org/oooo-0oo2-1725-0634. Email id: rittvika.singh@gmail.com 